\title{
UNITED NATIONS ASSISTANCE TO CONSTITUTION-MAKING PROCESSES: PRE-CONSTITUENT AND CONSTITUENT PHASES
}

\author{
ASSISTÊNCIA DAS NAÇÕES UNIDAS PARA OS PROCESSOS \\ DE CONSTITUTION-MAKING: FASES PRÉ-CONSTITUINTE E \\ CONSTITUINTE
}

\author{
CARINa Barbosa GouvêA" \\ JAYME BENVENUTO**
}

\begin{abstract}
The empirical evidences of constitution-making conducted by the United Nations (UN) represent a significant challenge to contemporary constitutional law and to the deeper tradition of modern constitutionalism. By incorporating the ideals that sustain democracy to the UN there was a change of perspective as to its role: the political-juridical structuring of a nation in turmoil. This paper discusses the pre-constituent and constituent stages of the constitutional assistance processes developed by the UN in states that have democratization needs. The focus of the discussion relates to the possibilities and limitations of such processes, led by the UN as an international institutional authority with the aim of being responsible for the appeasement of large areas of turmoil. Whether in the pre-constituent phase, or in the constituent phase, we are addressing politicallegal processes in which a global international organization interferes in the adoption or reform of a constitution by a national state. The fact reveals, firstly, the political, economic and social
\end{abstract}

\section{RESUMO}

As evidências empíricas de processos de construção de constituição realizadas pela Organização das Nações Unidas (ONU) representam um desafio significativo para o direito constitucional contemporâneo e para a tradição mais profunda do constitucionalismo moderno. A partir da incorporação dos ideais que sustentam a democracia a ONU houve uma mudança de perspectiva quanto ao seu papel: a estruturação político-jurídica de uma nação em crise. Este trabalho discute as fases pré-constituinte e constituinte dos processos de assistência constitucional desenvolvidos pela ONU em estados que apresentam necessidades de democratização. O foco da discussão se relaciona às possibilidades e às limitações de tais processos, conduzidos pela ONU em qualidade de autoridade institucional internacional com a pretensão de serem responsáveis pelo apaziguamento de amplos espaços territoriais conturbados. Seja na fase pré-constituinte, seja na fase constituinte, estamos abordando processos político-jurídicos em que uma organização

* Post Doctoral Internship - Federal University of Pernambuco (PPGD / UFPE); PhD and MS in Law from UNESA, Public Law and Social Evolution, Research Area Fundamental Rights and New Rights. Researcher of the Research Groups Laboratory of Comparative Latin American and European Studies (CECLAE); Global Comparative Law: Governance, Innovation and Sustainability (GGINNS). Professor of the Post-Graduate Program in Law - Masters and Doctorate, at the Federal University of Pernambuco (PPGD/UFPE).

E-mail: carinagouvea25@gmail.com.

* Professor Doctor of International Public Law. Master in Law at the Federal University of Pernambuco; Doctor in Law at the University of São Paulo; Postdoctorate in Human Rights International Law at the University of Notre Dame (USA). Professor of the Post-Graduate Program in Law - Masters and Doctorate; and of the Post-Graduate Program in Human Rights - Masters, at the Federal University of Pernambuco - UFPE. Productivity Scholar in Research 2 of the CNPq. Coordinator of the group of research Post coloniality and LatinAmerican Integration. E-mail: benvenutolima@uol.com.br. 
fragility of certain parts of the world - subject to fratricidal disputes that include the violence and the subjection of considerable parcels of their populations. Secondly, the fact reveals the difficulty that the global international system encounters in positioning itself adequately in the face of the problem without the marks of colonization. The problematization, from the subject of study, adopts a dogmatic profile and is promoted through an interdisciplinary approach, guided by the critical-dialectical model. It was undertaken, during the research of qualitative data collected from the real events, with the objective of explaining, exploring and describing current phenomena inserted in the analyzed context. Thus, the research is based in the following elements: doctrine and official documentation issued by the United Nations.

KEYWORDS: United Nations. Constitutionmaking processes. Pre-constituent phase. Constituent phase. internacional de caráter global interfere na adoção ou na reforma de uma constituição por parte de um estado nacional. O fato é revelador, em primeiro lugar, da fragilidade política, econômica e social de certas partes do mundo - sujeitas a disputas fratricidas que incluem a violência e a sujeição de parcelas consideráveis de suas populações. Em segundo lugar, o fato revela a dificuldade que o sistema internacional global encontra de se posicionar adequadamente diante do problema sem as marcas da colonização. A problematização, a partir do objeto de estudo, adota um perfil dogmático e é promovida através de um olhar interdisciplinar, norteada pelo modelo crítico-dialético. Foram coletados, no decorrer da pesquisa, dados qualitativos a partir de eventos reais, com o objetivo de explicar, explorar e descrever fenômenos atuais inseridos no contexto analisado. Assim, a pesquisa tem sede nos seguintes elementos: doutrina e documentos oficiais emitidos pelas Nações Unidas.

PALAVRAS-CHAVE: Nações Unidas. Processos de construção de constituição. Fase pré-constituinte. Fase constituinte.

\section{INTRODUCTION}

The idea that a global character international organization can act in processes of constitutionalisation, aiming to contribute to the institution of a national state and to the democratization of national states dates from the twentieth century, more precisely with the creation of the United Nations, in 1945.

Although there have been voices prior to this date that advocated international institutional action for global appeasement, political conditions were only established with the creation of the UN. The implementation of the idea was only possible thanks to the decolonization processes of vast territories, especially in Africa and Asia, for which the then new organization contributed. We must recall that in 1960 the UN General Assembly adopted the Declaration on the Granting of Independence to Colonial Countries and Peoples (Resolution 1514); and, in 1962, it established the Special Committee on Decolonization, in order to enforce the Declaration. The institution of the Committee sought to assign intelligibility and legitimacy to the UN in the field of internationalization of Law.

Let us remember that the Charter of the United Nations established, through its art. 75, the International Tutorship System, with which the organization began to encourage the processes of decolonization by establishing its authority in the administration and supervision of territories that could be placed under international protection. In the terms of art. 76 of the Charter 
of the United Nations, the intention was to promote international peace and security; to promote the political, economic, social and educational progress of the inhabitants of the protected territories; stimulate respect for human rights and fundamental freedoms, among other possibilities.

With the suspension of the activities of the UN Trusteeship Council in 1994, due to the criticism of its disciplinary character in imperialist terms of the international order, the advisory processes for the adoption of national constitutions in democratic terms began to gain space.

The paradox contained in both the earliest and the most recent processes is the existence of an international institutional authority to establish the rules of what must be considered democratic. On the other hand, let us consider the challenge posed for a global international organization, committed to peace and human rights, to act in a space in which the most varied human groups act with the objective of capturing the state for purposes that are not in line with human rights and individual freedoms, in situations that can deteriorate even in the practice of international crimes.

\section{CONSTITUTION-MAKING PROCESSES}

According to Widner ${ }^{1}$, in the last forty years, more than two hundred new constitutions were adopted by countries that presented internal violence. This experience, which began to incorporate foreign agents, assumes significant questionings about the concept of constitutionalism employed and its ability to guide the process of institutional restructuring.

Let us consider, according to Teitel ${ }^{2}$, that democratization in periods of change aims at the construction of the political order, being fundamentally constitutive of the perception that involves the study of the nature of the type of constitutionalism employed.

It is in this sense that we must question the role played by the UN in the emergence of a constitutionalism that we would qualify as symbolic or transitional, therefore, transformative.

Referring to nations lacking in more pronounced democratic traditions, international intervention may prove to be of paramount importance. Through it, the shaping of a process of constitutionalisation of a new democratic order is sought, which provides economic and political support to the institutional for its very own support and implementation of new values. The result to be achieved may also be the opposite, provoking new and successive social destabilization.

1 WIDNER, Jennifer. Constitution writing in post-conflict settings: an overview. William \& Mary Law Review, V. 49, Issue 4, 2008, p. 1513.

2 TEITEL, Ruti G. Transitional justice genealogy. Harvard Human Rights Journal, Vol. 16, 2003, p. 70. Disponível em: <http://www.law.harvard.edu/students/orgs/hrj/iss16/teitel. pdf $>$. Acesso em: 11 dez. de 2012. 
The adoption of transitional change, according to $\mathrm{Barros}^{3}$, has been happening and being justified on a global scale due to five factors: (i) the decolonization process, after World War II, whose emphasis revolved around the creation of new sovereign States, in which the choice of procedure to be taken to deal with the situation was partly influenced by domestic factors such as the complexity and diversity of society; (ii) democratization, initially in Latin America and part of Asia and later in Africa, whose aim was to deepen democratic practice; (iii) the collapse of Communism, with the consequences of regime change for the relatively strong states of Central Europe and the Baltic States; (iv) the institutional crises of democratic constitutional states, whether in contexts related to the collapse of Communism or in certain parts of Africa where there was a low institutional framework; ( $v$ ) and the elaboration of a post-conflict letter that has attracted significant attention, once it is directed to the reconstruction of a political community and the structures of the State.

The causes, forms, and rhythm of these different tendencies varied considerably, but they shared a characteristic, simultaneous, dominant movement toward more liberal and often more democratic governance known as a global democratic trend that thanks to Samuel Huntington ${ }^{4}$ came to be widely known as the third wave of democracy.

Most of these new political systems, in addition to democratic institutions, have a form of active judicial review. Constitutional courts have emerged as translators of provisions designed to guide constitutional life. This transit has been intense and reflects what may be called a "supposedly universal speech" .

These manifestations eventually created constitutional charters with similar patterns from a liberal matrix, which provokes a reflection on the actual "power relation" produced ${ }^{6}$. This means an openness to participation, considering its architectural design and its development.

According to $\mathrm{Richie}^{7}$, this architecture must be organically connected so that the concept of 'constitutional belonging' can develop, relative to the level of

3 WORKSHOP ON CONSTITUTION BUILDING PROCESSES, 2007. Nova Jersey. Workshop Report. Nova Jersey: Bobst Center for Peace \& Justice; Princeton University; International IDEA, 2007. p.5.

4 HUNTINGTON, Samuel P. The Third Wave: democratization in the late twentieth century. University of Oklahoma Press: Norman and London, 1991, p.17.

5 HIRSCHL, Ran. From comparative constitutional law to comparative constitutional studies. International Journal Constitutional Law, 2013, v. $11 \mathrm{n}^{\circ}$ 1, p. 1-12.

6 SBURG, Tom; MELTON, James; ELKINS, Zachary. This endurance of national constitutions. University of Chicago Law \& Economics Working, Paper N ${ }^{\circ}$. 511, Janeiro 2010, p.1-11. Disponível em: <http://papers.ssrn.com/sol3/papers.cfm?abstract_id=1536925>. Acesso em: 20 de mar. de 2014.

7 RICHIE, David. Pertencimento constitutional. Trad. Izabel Nuñez. In: ASENSI, Felipe Dutra; DE PAULA, Daniel Giotti (Coord.).Tratado de direito constitucional: constituição, política e sociedade. Vol. I. Rio de Janeiro: Elsevier, 2014, p. 308. 
investment that a people must have over a document that is the legal and political basis of the nation-state in which lives.

An accessible, yet powerful, view cannot be overlooked: constitutions neither originate nor operate in a vacuum. Its importation cannot be described or explained independently of the social, political and economic, national and international forces.

The UN (2002) $)^{8}$ considers that democracy is consolidated over time and its continuity depends on the long and continuous exercise of democratic life. The international body acts in the consolidation of democracy through the politicaljuridical structuring in the processes of building a constitution that develops in three distinct phases: the pre-constituent; the constituent and the post-constituent. This paper addresses the pre-constituent and constituent phases that will be developed in the next chapter.

\section{INTERVENTION IN THE PRE-CONSTITUENT PHASE}

The pre-constituent intervention is the one in which UN aid links three specific moments: support for election campaigns; intervention in educational campaigns and intervention in popular participation ${ }^{9}$.

\subsection{SUPPORT FOR ELECTION CAMPAIGNS}

International cooperation ${ }^{10}$ in electoral matters is centered on the aspect of representative democracy that refers to democratic access to power ${ }^{11}$. Facing the face of the waves of democratization, since the 1970s, the process was more directed towards the promotion of human development and led to the opening of political systems and the expansion of regimes of freedoms ${ }^{12}$.

8 United Nations Organization. (2002) General meeting. Studies on the common challenges of States in their efforts to ensure democracy, the rule of law and human rights. Resolução A/HRC/22/29. <http://www.ohchr.org/Documents/HRBodies/HRCouncil/RegularSession/ Session22/A.HRC.22.29_English.pdf>.

9 GOUVÊA, Carina B. As Intervenções da ONU no Processo de Constitution-Making nos Estados em Transição Política : O Papel das Nações Unidas no Resgate da Ordem Democrática. 1. ed. Curitiba/PR: Juruá Editora, 2016, p. 130.

10 TOLER, Lorianne Updike. Mapping the constitutional process. Cambridge Journal of International and Comparative Law, Vol.3 nº4, 2014, p. 1260-1286. Disponível em: <http://cjicl.org. uk/archive/>. Acesso em: 18 de ago. de 2015.

11 CARRILLO, Manuel. Cooperación Internacional. In: NOHLEN Dieter, ZOVATTO Daniel, OROZCO Jesús, THOMPSON José (Org.). Tratado de Derecho Electoral comparado de América Latina. 2. ed. México: Fondo de Cultura Económica, Instituto Interamericano de Derechos Humanos, Universidad de Heidelberg, International IDEA, Tribunal Electoral del Poder Judicial de la Federación, Instituto Federal Electoral, 2007, p.84.

12 PNUD. (2002) Human Development Report 2002: deepening democracy in a fragmented world. New York: Trinova Editor,2002, p.1According to the UNDP / UNDP, in a report from 1973 to 200393 countries went to democracy; in the 1970 s there were 08 countries; in the 1980s, 23 countries and between 1990 and 2003 were 62 countries. Of the 191 member countries of the United Nations, in 140 of them they had democratic elections. This analysis represents the data collected in the year 2007. 
In this sense, there was a broadening of electoral matters to develop institutions, procedures, strategies, models, programs and intellectual production centers that had as their purpose the cooperation and strengthening of the international community in order to support this process, duly recognized by the transition constitutionalism.

By its very nature, post-conflict democratic assistance is a dynamic process and at the same time a boiling cauldron. Operating in hostile environments with limited infrastructure and significant pressure, it helps to illustrate the positive role of the UN in the pre-constituent phase towards governance. According to Carrillo ${ }^{13}$, this is a valuable aid ${ }^{14}$ to meet the needs of countries in transition by building, improving and strengthening their electoral systems and bodies.

In most countries involved in redemocratization processes, there is usually a social and political critique that electoral processes would be involved in fraud and irregularities and would be responsible for changing the popular will ${ }^{15}$. In this regard, it should be emphasized that credibility in the outcome of elections, as well as the improvement of electoral systems, depend directly on a combination of factors, including internal political conditions, country culture and the degree of professionalization of political institutions ${ }^{16}$.

13 CARRILLO, Manuel. Cooperación Internacional. In: NOHLEN Dieter, ZOVATTO Daniel, OROZCO Jesús, THOMPSON José (Org.). Tratado de Derecho Electoral comparado de América Latina. 2. ed. México: Fondo de Cultura Económica, Instituto Interamericano de Derechos Humanos, Universidad de Heidelberg, International IDEA, Tribunal Electoral del Poder Judicial de la Federación, Instituto Federal Electoral, 2007, p.88.

14 Horacio Boneo; Manuel Carrillo; Ricardo Valverde. La observación internacional y nacional de las elecciones. In: NOHLEN Dieter, ZOVATTO Daniel, OROZCO Jesús, THOMPSON José. Tratado de Derecho Electoral comparado de América Latina. (2007) 2. ed. México: Fondo de Cultura Económica, Instituto Interamericano de Derechos Humanos, Universidad de Heidelberg, International IDEA, Tribunal Electoral del Poder Judicial de la Federación, Instituto Federal Electoral, 1074. In the elections that took place in South Africa in 1994, UN participation was clearly aimed at reducing the level of violence; the same occurred in the Haitian elections in 1991. Their presence in Haiti has helped considerably to contain domestic violence and to facilitate the way to deal with differences, including technical elections, as well as security and protection of citizenship, considerably reducing the spread of political violence. Initially, the forces were focused on the organization to replace the holders of power and guarantee clean, transparent and reliable elections that clearly reflected the popular will as a neutral mediator able to guarantee impartiality. The work was evolving and the degree of action was broadened beyond the day of the election, to consider also the preparatory acts and after the electoral day.

15 CARRILLO, Manuel. Cooperación Internacional. In: NOHLEN Dieter, ZOVATTO Daniel, OROZCO Jesús, THOMPSON José (Org.). Tratado de Derecho Electoral comparado de América Latina. 2. ed. México: Fondo de Cultura Económica, Instituto Interamericano de Derechos Humanos, Universidad de Heidelberg, International IDEA, Tribunal Electoral del Poder Judicial de la Federación, Instituto Federal Electoral, 2007, p.100.

16 CARRILLO, Manuel. Cooperación Internacional. In: NOHLEN Dieter, ZOVATTO Daniel, OROZCO Jesús, THOMPSON José (Org.). Tratado de Derecho Electoral comparado de América Latina. 2. ed. México: Fondo de Cultura Económica, Instituto Interamericano de Derechos Humanos, Universidad de Heidelberg, International IDEA, Tribunal Electoral del Poder Judicial de la Federación, Instituto Federal Electoral, 2007, p.102. 
Despite the intervention promoted by the UN, there are cases in which the consolidation of democracy has advanced slowly, like Nicaragua; while in others there is a clear regression, as in Haiti ${ }^{17}$. According to Hampson ${ }^{18}$, an interesting suggestion to avoid regression would be to pair the elections with forms of power sharing. Stability among political factions can be established by dividing power between coalition forces.

International assistance to political parties focuses on individual and system-wide support, whose goal is to strengthen representative democracy ${ }^{19}$, as the system functions for the purpose of developing coherent government policies and programs, exercising the function of articulating interests; connects social demands and consolidates them; articulates interests; selects and trains candidates to hold positions in government and legislature; oversees and controls government actions.

Consider, therefore, that elections in conflict situations usually act as a catalyst for the development of parties and other organizations that are, in certain situations, the only vehicle to help the local elites to gain access to the established power ${ }^{20}$. Unless there is some form of compensation, those who lose at the polls can have a strong incentive to take up arms again and resort to the use of force in order to achieve their political goals ${ }^{21}$.

As seen, the process of democratization is not uniform and linear and it is not enough to solely and exclusively serve the electoral system to solve problems related to governance. International experience has shown that it is necessary to integrate the strengthening of civic education and popular participation in the cooperation plan. These are two democratic pillars without which the democratic process is weakened.

17 BONEO Horacio; CARRILLO, Manuel; VALVERDE, Ricardo. La observación internacional y nacional de las elecciones. In: NOHLEN Dieter, ZOVATTO Daniel, OROZCO Jesús, THOMPSON José (Org.). Tratado de Derecho Electoral comparado de América Latina. 2. ed. México: Fondo de Cultura Económica, Instituto Interamericano de Derechos Humanos, Universidad de Heidelberg, International IDEA, Tribunal Electoral del Poder Judicial de la Federación, Instituto Federal Electoral, 2007, p.1105.

18 HAMPSON, Fen Osler. Can peacebuilding work. Cornell International Journal, volume 30, no 3, Artigo 5, 1997, p. 701-716. Disponível em: <http://scholarship.law.cornell.edu/cilj/vol30/ iss3/5>. Acesso em 30 de abr. de 2015, p. 710.

19 CATÓN, Matthias. Effective party assistance: stronger parties for better democracy. Stockholm: International IDEA, 2007, p. 6-7.

20 REILLY, Benjamin. Electoral assistance and post-conflict peacebuilding: what lessons have been learned? Asia Pacific School of Economics and Government Australian National University, Vol. 200, 2004, p. 4. Disponível em: <http://aceproject.org/ero-en/topics/elections-security/ Reilly-2505.pdf>. Acesso em: mar. de 2014.

21 In Chile, the promulgation of the 1980 Charter, without popular participation, under the mantle of the dictatorship and after a fraudulent plebiscite, ended up fueling the conflict even more, mainly because it promoted the segregation of other parties. It is the pre-constitution factors that can shape a better response to the conformation of dissent already constituted. In Cambodia, for example, the parties recognized from the outset that a coalition government was needed to appease groups and advance the process of national reconciliation. 
Above all, representative democracy helps us solve many issues, but it will always be in permanent deficit if it is not accompanied by competing actions that tend to improve and enrich parties and governability ${ }^{22}$.

Those countries that demonstrate the capacity to renew, over time, both their institutional and opening-democratic-space alliances, as well as the methods that are projected in a broad spectrum - ranging from the organization, through civic education and, the generation of democratic and technical doctrine on electoral observation ${ }^{23}$ have great possibilities for gradually achieving democratic development.

The UN's choices are made on the basis of crucial issues involving the electoral system, power sharing structures and the transformation of rebel forces into political parties. Such choices have far-reaching consequences for the scope and pace of democratic transition ${ }^{24}$.

But it is necessary to confine ourselves to the weaknesses that, at first glance, may seem contradictory: the lack of systemic methodology and insufficient contextualization $^{25}$. As for the first, it means that there is no general framework to deal with what is supposed to mean assistance to political parties and how programs should be implemented. As for the second, it refers to the way that care providers use their strengths; that is, they tend to repeat the same solutions in all contexts or simply replicate the experiences of other countries.

This weakness can come from the composition of the assistance, since traditionally it is formed by Western consultants. Despite being very well informed about how a consolidated democracy works, the states in question have never experienced a democratic transition and are therefore less able to appreciate the dynamics and subtlety involved in the actual process of democratization ${ }^{26}$.

22 CARRILLO, Manuel. Cooperación Internacional. In: NOHLEN Dieter, ZOVATTO Daniel, OROZCO Jesús, THOMPSON José (Org.). Tratado de Derecho Electoral comparado de América Latina. 2. ed. México: Fondo de Cultura Económica, Instituto Interamericano de Derechos Humanos, Universidad de Heidelberg, International IDEA, Tribunal Electoral del Poder Judicial de la Federación, Instituto Federal Electoral, 2007, p.107.

23 BONEO Horacio; CARRILLO, Manuel; VALVERDE, Ricardo. La observación internacional y nacional de las elecciones. In: NOHLEN Dieter, ZOVATTO Daniel, OROZCO Jesús, THOMPSON José (Org.). Tratado de Derecho Electoral comparado de América Latina. 2. ed. México: Fondo de Cultura Económica, Instituto Interamericano de Derechos Humanos, Universidad de Heidelberg, International IDEA, Tribunal Electoral del Poder Judicial de la Federación, Instituto Federal Electoral, 2007, p.1105.

24 TEN HOOVE, Lotte; SCHOLTBACH, Alvaro Pinto; MAUL-PHILLIPS, Joy. Democracy and political party assistance in post-conflict societies. Netherlands Institute for Multiparty Democracy, NIMD Knowledge Centre, 2008, p.9.

25 CATÓN, Matthias. Effective party assistance: stronger parties for better democracy. Stockholm: International IDEA, 2007, p. 19.

26 LAPPIN, Richard. What democracy? Exploring the absent center of post-conflict democracy. Assistance Journal of Peace Conflict and Development, $\mathrm{n}^{\circ}$ 14, Julho 2009, p.17. Disponível em: <www.peacestudiesjournal.org.uk>. Acesso em: 05 de ago. de 2015. 
According to Lappin ${ }^{27}$, the speech especially brought by the United States in support of democracy has been approached as a form of national security and protection of western States. In this sense, the product ends up being valued by the western look instead of being a process that values the identity of those in need of international support.

Lappin $^{28}$ further states that any democracy assistance project can undoubtedly be considered paternalistic because it implies a transfer of knowledge to those who do not have the basic capacity or understanding to achieve development on their own.

The situation is aggravated as the solutions offered have little relation to the realities experienced by those seeking to rebuild society. This challenge will be softened by creating a social space where perspectives and contrasts can come together and where actors can recognize their interdependence and negotiate a peaceful and mutually shared future.

A good option was found by Michel and Cofone ${ }^{29}$, supporting a qualified referendum to enforce the charter bill. If the foundation is to include all social groups in the process, since they tend to directly influence the stability and legitimacy of the charter, then it is reasonable to consider that special attention should be paid to them in the choice phase. The voting rules in the constitutional set must ensure that these groups can exert some influence on the result and the rules of qualified majority can directly achieve popular participation.

The "two-thirds" rule in promoting consensus has been widespread for constituent assemblies, as for example in Egypt, Tunisia and Libya. But this demand should also be reached in popular ratification via the referendum.

The qualified majority rule aims to hear everyone who is part of the procedure and this inclusion is able to validate the constitutional identity of the subject, which connects it to a responsive response that qualifies and legitimizes the process.

The choice ${ }^{30}$ of the type of electoral system will depend on the specific situation of the country in question, but it should cover its political culture, its history in representative democracy, the size of parliament, knowledge of the electorate and the quality of its organizations and leadership policies, rather

27 LAPPIN, Richard. What democracy? Exploring the absent center of post-conflict democracy. Assistance Journal of Peace Conflict and Development, $\mathrm{n}^{\circ}$ 14, Julho 2009, p.17. Disponível em: <www.peacestudiesjournal.org.uk>. Acesso em: 05 de ago. de 2015.

28 LAPPIN, Richard. What democracy? Exploring the absent center of post-conflict democracy. Assistance Journal of Peace Conflict and Development, $\mathrm{n}^{\circ}$ 14, Julho 2009, p.23. Disponível em: $<$ www.peacestudiesjournal.org.uk>. Acesso em: 05 de ago. de 2015.

29 MICHAEL, Stephan; COFONE, Ignacio N. Fixing popular participation in constitution-making. Rotterdam Institute of Law and Economics, Erasmus University Rotterdam, № 2015/02, p.1-23. Disponível em: <http://ssrn.com/abstract=2580849>. Acesso em: 15 mai. de 2015.

30 REYNOLDS, Andrew; REILLY, Ben; ELLIS, Andrew. Diseño de sistemas electorales: el nuevo manual de IDEA Internacional. Trad. Carlos Navarro Fierro. IDEA Internacional, 2006, p.8. 
than being a "one-size-fits-all” approach, generally considered the best remedy for all post-conflict scenarios ${ }^{31}$.

In a divided society, the electoral system should not only promote proportional representation, but mainly provide incentives for political parties in order to avoid party fragmentation and lack of governance.

The UN intervention in support of promotion and institutional development in electoral campaigns demonstrates that the use of its expertise helps to improve and strengthen electoral systems and bodies. And, as an impartial body to participate in the process, it ends up giving credibility to the electoral process.

These practices developed by the UN can be translated as an "active stimulus" of the local community, strengthening civic virtue and the growth of solidarity through the direct bet on the postulates that require a nation in transition.

\subsection{INTERVENTION IN EDUCATIONAL AND POPULAR PARTICIPATION CAMPAIGNS}

The most successful constitutions from comparative studies were those involving significant popular participation mechanisms. This participation must be preceded by impartial civic intervention, according to $\operatorname{Toler}^{32}$. Colón-Rios ${ }^{33}$ had already warned us that in order to satisfy democratic legitimacy the process of constitutional creation must allow for the greatest possible participation of those who will be subject to it.

The goal is to help the public to participate and to know what their constitutional choices are. Starting transformations related to the political culture of a society is one of the most difficult aspects of any democratic transition. It requires substantial changes in behavior as well as expectations. The use of standards requires long-term strategies, involving large segments of society with extensive education and sensitization campaigns, as well as dialogue and consensus-building. The main purpose of this activity is to increase democratic participation, particularly for women, the poor, indigenous groups and other underrepresented segments of society. It includes sensitization promotion activities

31 TEN HOOVE, Lotte; SCHOLTBACH, Alvaro Pinto; MAUL-PHILLIPS, Joy. Democracy and political party assistance in post-conflict societies. Netherlands Institute for Multiparty Democracy, NIMD Knowledge Centre, 2008, p.11.

32 TOLER, Lorianne Updike. Mapping the constitutional process. Cambridge Journal of International and Comparative Law, Vol.3 n4, 2014, p. 1272. Disponível em: <http://cjicl.org.uk/ archive/>. Acesso em: 18 de ago. de 2015.

33 CÓLON-RIOS, Joel. Apuntes sobre legitimidad democrática y asambleas constituyentes. $R e$ vista Argentina de Teoría Jurídica, Vol. 16, Dezembro de 2015, p.1-11. Disponível em: <http:// www.utdt.edu/ver_contenido.php?id_contenido=11169\&id_item_menu=5858>. Acesso em: 8 de jan. de 2016. 
to highlight the rights and responsibilities of citizens, components of society they want to build ${ }^{34}$.

These intangible aspects of democracy building are often neglected. There is a lot of uncertainty about the impact of different governance structures options because it requires a complex interaction between the various institutions of a particular historical environment.

Although it cannot be considered as an element of constitutional success, the constitutions of Norway, South Africa, and Kenya are considered strong in popular participation in the consultations held internally on constitutional content ${ }^{35}$.

In South Africa, an independent electoral commission developed a plan that was divided into a number of items such as population education on the special nature of elections to constituent assemblies; the call for popular participation in different dialects; and the fight against illiteracy.

In Cambodia, for the elections, the UNTAC (United Nations Transitional Authority in Cambodia) teamed up with the Human Rights Task Force, civil servants, monks, judges, NGOs to develop constitutional literature through mass communication efforts. This eventually mobilized 4.6 million Cambodians to vote in the elections and especially inspired women of the Buddhist clergy to get involved in the process of the written constitution ${ }^{36}$.

Public participation cannot become significant if it does not take place in formats that can be easily incorporated by the drafters, either because of the volume or because of the nature of the proposals. In Iceland, because it is relatively smaller than South Africa, the process has proved to be more useful and more homogeneous.

Successful participation presents the public with real choices, in Toler's qualification ${ }^{37}$. In Morocco, the public received propaganda from the monarchy rather than information presenting constitutional choices. In Iraq, the information was less biased, but failed to focus on important issues, which ended up preventing

34 REILLY, Benjamin. Electoral assistance and post-conflict peacebuilding: what lessons have been learned? Asia Pacific School of Economics and Government Australian National University, Vol. 200, 2004, p. 8. Disponível em: <http://aceproject.org/ero-en/topics/elections-security/ Reilly-2505.pdf>. Acesso em: mar. de 2014.

35 TOLER, Lorianne Updike. Mapping the constitutional process. Cambridge Journal of International and Comparative Law, Vol.3 n 4 4, 2014, p. 1273. Disponível em: <http://cjicl.org.uk/ archive/>. Acesso em: 18 de ago. de 2015.

36 GOUVÊA, Carina B. As Intervenções da ONU no Processo de Constitution-Making nos Estados em Transição Política: O Papel das Nações Unidas no Resgate da Ordem Democrática. 1. ed. Curitiba/PR: Juruá Editora, 2016, p. 137.

37 TOLER, Lorianne Updike. Mapping the constitutional process. Cambridge Journal of International and Comparative Law, Vol.3 $\mathrm{n}^{\circ} 4$, 2014, p. 1274. Disponível em: <http://cjicl.org.uk/ archive/>. Acesso em: 18 de ago. de 2015. 
the public from affecting the outcome on these matters. Lack of precision tends to preclude widespread popular adherence.

These problems are also directly contaminated when the time for consultations tends to be eminently short, as in Afghanistan, Iraq and East Timor.

The impact of participation is also greatly impaired by political maneuvers ${ }^{38}$. In Kenya, the legislature rewrote the constitution denying much of the popular comments. In Eritrea, the consultation process was widely praised in its various phases, although it was frustrated by the President who refused to implement the letter and hold new elections.

One of the best ways to ensure public education is a transparent process and good record keeping that can be shared with the public, which has been considered essential for constitutional success. In Eritrea, whose UN intervention was considered moderate, public mass meetings were held in 157 different locations throughout the country, all recorded. In Kenya, in 2005, although the meetings of the constitutional commissions were not opened, public reports on long deliberations were produced and the letter incorporated the results of the extensive campaign.

An alternative is the inspiration that transitional constitutionalism is capable of highlighting, the elaboration of the participatory constitution, which can provide a forum for the negotiation of open solutions, involving controversial issues, resulting in an expansion and democratic formation of the population in order to, gradually, achieve a process of appeasement and reconciliation and to forge a consensus view on the future of the State.

This popular inclusion reflects a measure of success, since it can influence the durability factor, the reduction of violence and political awareness. Its purpose is to bring together as many groups as possible to broaden the dialogue and to shape constitutional dissent. The shared and open environment, through public hearings, local, regional and sector conferences or requests to express their opinions in research, make a great difference in the sense of integrating wills, which has been diminished in ordinary processes. In hostile environments, most of the time, communication channels are limited or dominated by a group.

In this line of thought, one can think of the participation that encompasses the unity and stability of society, tolerating and valuing the plurality of conceptions, characteristics of a free democratic culture, with potentially conflicting goods and values. The unity of society and the fidelity of the citizen-people to the common institutions are not based on the fact that everyone adheres to the same conception of good, but in the fact of publicly accepting a political conception of justice, admitted as a current and legitimate way to govern the structure of society.

38 TOLER, Lorianne Updike. Mapping the constitutional process. Cambridge Journal of International and Comparative Law, Vol.3 nº 4, 2014, p. 1275. Disponível em: <http://cjicl.org.uk/ archive/>. Acesso em: 18 de ago. de 2015. 


\section{THE INTERVENTION IN THE CONSTITUENT PHASE}

\subsection{THE CONTRIBUTION IN THE DESIGN OF THE CONSTITUENT PROCESS ANDTHE ENUNCIATIONOFTHECONSTITUTIONAL CONTENT}

The involvement of the United Nations in the constituent phase can be perceived from premises established by the organization and may vary from technical-legal knowledge to the structure of the process and fundamental constitutional principles ${ }^{39}$.

These practices invest in different methods that include both the encouragement of compliance with the international standards in national charters for the realization of human rights, as well as participation in constituent assemblies as a political advisor. For the UN, aid will also contribute to broadening knowledge about national actors and helping them to explore solutions that are technically sound and possibly consistent with long-term stability.

All constitutions considered successful included local specialists in the design of their process. Mapped by Toler ${ }^{40}$, this was the case in Norway, Poland and South Africa, where the assemblies were constituted by national jurists. In the South African experience, international influence only occurred after the presentation of a first project.

We understand that too much international influence can be detrimental to a constitutional process considering that the result may be inappropriate for local needs. The Afghan charter was effectively rewritten by international interests, producing a document with little local interest ${ }^{41}$.

Haiti, in February 2004, became once again an unstable country after at least 10 years of national reconstruction efforts from international intervention; Liberia has had at least two rounds of international intervention since the UN oversaw the 1997 elections; there is daily violence in Iraq and there is ongoing instability in Afghanistan; Kosovo has long been under the mantle of the United Nations administration, with an uncertain future and continuous currents of conflict ${ }^{42}$.

39 GOUVÊA, Carina B. As Intervenções da ONU no Processo de Constitution-Making nos Estados em Transição Política: O Papel das Nações Unidas no Resgate da Ordem Democrática. 1. ed. Curitiba/PR: Juruá Editora, 2016, p. 139.

40 TOLER, Lorianne Updike. Mapping the constitutional process. Cambridge Journal of International and Comparative Law, Vol. $3 \mathrm{n}^{\circ} 4$, 2014, p. 1279. Disponível em: <http://cjicl.org.uk/ archive/>. Acesso em: 18 de ago. de 2015.

41 TOLER, Lorianne Updike. Mapping the constitutional process. Cambridge Journal of International and Comparative Law, Vol.3 n4, 2014, p. 1280. Disponível em: <http://cjicl.org.uk/ archive/>. Acesso em: 18 de ago. de 2015.

42 SAMUELS, Kirsti. Post-Conflict peace-building and constitution-making. Chicago Journal of International Law, V. 6, N² 2, 2006, p. 663-682. Disponível em: <http://chicagounbound.uchi- 
According to Samuels ${ }^{43}$, there is no shortage of theories for the failure to construct a constitution in post-conflict settings. Some focus on the operational limitations and unintended negative consequences of international aid, while others focus on the institutional gap.

On average, at least $50 \%$ of emerging states in conflict return to the initial situation. According to Collier and Hoeffler ${ }^{44}$, civil war is in itself such a profound experience for a society that it is likely that further events will not take place, such as the institution of elections, the adoption of constituent assemblies and referendums. The investigations of the authors mentioned revealed that, after the end of the conflict, in the 21 countries investigated during the period 1965 1999 , the predicted risk for new insurgencies rose by $38.6 \%$. If stabilization is maintained, the risk gradually diminishes.

The intervention of the international community ends up grafting devices that directly influence the key issues of the charter and its development ${ }^{45}$. There may be affectation of content, of the agenda, of the choice of forum and a variety of other aspects.

The choice of process and its terms may end up valuing the international system, with special attention to international conventions. What can be concluded, according to Barros ${ }^{46}$, is that agreements are concluded by experts who generally understand the immediate political context, but who cannot understand the long-term implications of the constitutional provisions that they advocate.

There is no way to size the complexity of these processes and the wide variety of factors that influence their outcomes ${ }^{47}$. The most representative and inclusive building processes were those that favored free and fair elections, greater political equality, social justice provisions, protection of human rights and strong accountability mechanisms.

cago.edu/cgi/viewcontent.cgi article=1476\&context=cjil>. Acesso em: 17 de jan. de 2014 .

43 SAMUELS, Kirsti. Post-Conflict peace-building and constitution-making. Chicago Journal of International Law, V. 6, N 2, 2006, p. 663-682. Disponível em: <http://chicagounbound.uchicago.edu/cgi/viewcontent.cgi? article=1476\&context=cjil>. Acesso em: 17 de jan. de 2014 .

44 COLLIER, Paul; HOEFFLER, Anke. The challenge of reducing the global incidence of civil war. Copenhagen Consensus Challenger Paper. Centre for the Study of African Economies, Department of Economics, Oxford University, Março 2004. Disponível em: <http://www.copenhagenconsensus.com/sites/default/files/CP\%2B\%2BConflicts\%2BFINISHED.pdf $>$. Acesso em: 25 de nov. de 2014 .

45 WORKSHOP ON CONSTITUTION BUILDING PROCESSES, 2007. Nova Jersey. Workshop Report. Nova Jersey: Bobst Center for Peace \& Justice; Princeton University; International IDEA, 2007, p.18.

46 WORKSHOP ON CONSTITUTION BUILDING PROCESSES, 2007. Nova Jersey. Workshop Report. Nova Jersey: Bobst Center for Peace \& Justice; Princeton University; International IDEA, 2007, p.16-18.

47 MCCOOL Carolyn. The Role of Constitution-Building Processes in Democratization: Afghanistan Case Study. Intl IDEA, 2004, s/p. 
For Barros $^{48}$, a charter written in the context of high rates of violence and insecurity tends to make work much more difficult, since conducting electoral deliberations or projects ends up exacerbating political passions and causes extreme difficulties for both exercises to achieve success.

There are several risks and consequences associated with writing an official document in conflict resolution, which may include: the possibility of adverse factions wanting to consecrate their power; the emergence of new political interests in order to claim a seat on the negotiating table; the exclusion of groups from the negotiations, usually minorities; the exclusion of non-combatants from the process; the sense of the lack of belonging of the local community, due to the composition of the negotiators and the domination exercised by the international mediators.

The legal constitution should not seek to build the state in an abstract and theoretical way, where there is no force to be aroused. This - which stems from the nature of things - cannot be a mere document to lend direction to it; if important cultural, social, political, and economic laws are ignored, it would lack the essential germ of its life force ${ }^{49}$. According to Hesse ${ }^{50}$, the document becomes an active force, if not only the will of power, but also the will of the constitution become present in the general consciousness, particularly in those of the main constitutional order. It should not be based on a unilateral structure if it is to prove its strength in a world in the process of permanent political and social change.

In order to think about the contribution of the UN in the constituent process it is necessary to measure the size of its action and how it will be perceived in the final project of a fundamental charter. The combination of forces - understood here as a process open to participation, coupled with local needs where the UN functions as an "advisory" body - would be able to overcome some structural and substantial problems, since it focuses the forces of claim not in a previously established model, but built by the inner hands.

\subsection{THE COMPOSITION OF THE CONSTITUENT ASSEMBLY: IN SEARCH OF CONSTITUTIONAL LEGITIMACY}

The theory of constitution has a valuable contribution to how constitutions and their mechanisms are elaborated ${ }^{51}$. In this sense, creating constitutions

48 WORKSHOP ON CONSTITUTION BUILDING PROCESSES, 2007. Nova Jersey. Workshop Report. Nova Jersey: Bobst Center for Peace \& Justice; Princeton University; International IDEA, 2007, p. 25.

49 HESSE, Konrad. A força normativa da constituição. Trad. Gilmar Ferreira Gomes. Porto Alegre: Sérgio Antônio Fabris, 1991, p. 4.

50 HESSE, Konrad. A força normativa da constituição. Trad. Gilmar Ferreira Gomes. Porto Alegre: Sérgio Antônio Fabris, 1991, p. 4.

51 ELSTER, Jon. Forças e mecanismos no processo de elaboração da constituição. Trad. Eliana 
involves making choices within certain constraints. In most cases, such choices are collective and are the result of the work of a constituent assembly. The composition of the constituent assembly is mostly formed of local political actors and societal forces ${ }^{52}$.

This promotion was developed in different stages and that for Hippel ${ }^{53}$ meant demilitarization, denazification or reeducation of an entire population. The priority has been to restrain communist advances and not to actually implement democratic reforms. The promotion of democracy is based on the hypothesis that they rarely wage war against each other, and therefore a growth in the number of democratic states would imply in a more secure and peaceful world.

The conditions in which a country enters in a constitution creation process were identified and the following consideration will be to understand the internal Dynamics of such process ${ }^{54}$. Traditionally, both methods involve the creation of a text, which has been made through constitutional assemblies made especially for this purpose or through legislatures that are proposing a substitution constitution or, more limitedly, by constitutional amendments. The latter involves the interpretation of provisional constitutions that have been elaborated by specialized constitutional courts or generalist courts ${ }^{55}$.

The constitutional construction model through a constitutional assembly which Schmitt, according to Arato ${ }^{56}$, considers fully democratic involves: the dissolution of all powers previously constituted; a popularly elected or acclaimed assembly with full powers; a provisional government based entirely on this assembly; a constitution led to a national and popular referendum; the dissolution of the constituent assembly after the ratification of the constitution, which establishes in a timely manner the government constituted.

Valadares Santos. In: BIGONHA, Antônio Carlos Alpino; MOREIRA, Luiz (Org.). Limites do controle de constitucionalidade. Rio de Janeiro: Lumen Juris, 2009, p. 9.

52 ARATO, Andrew. Construção constitucional e teorias da democracia. Lua Nova: Revista de Cultura e Política [on line]. 1997, n ${ }^{\circ} 42$, p. 5. Disponível em: <http://www.scielo.br/pdf/ln/n42/ a02n42.pdf>. Acesso em 24 de ago. de 2012.

53 HIPPEL, Karin von. Democracia pela força. Trad. Joubert de Oliveira Brízida. Rio de Janeiro: Biblioteca do Exército Brasileiro, 2003, p.21.

54 ELSTER, Jon. Forças e mecanismos no processo de elaboração da constituição. Trad. Eliana Valadares Santos. In: BIGONHA, Antônio Carlos Alpino; MOREIRA, Luiz (Org.). Limites do controle de constitucionalidade. Rio de Janeiro: Lúmen Juris, 2009, p. 18.

55 TUSHNET, Mark. Novos Mecanismos institucionais para a criação do direito constitucional. Trad. Thiago Filippo Silva Jorge. Quaestio Iuris, Vol. 08, $\mathrm{n}^{\circ}$ 02, Rio de Janeiro, 2015, p.1189. Disponível em: <http://www.e-publicacoes.uerj.br/index.php/quaestioiuris/article/ view/16915>. Acesso em: 15 de fev. de 2016.

56 ARATO, Andrew. Construção constitucional e teorias da democracia. Lua Nova: Revista de Cultura e Política [on line]. 1997, no 42, p. 17. Disponível em: <http://www.scielo.br/pdf/ln/ n42/a02n42.pdf>. Acesso em 24 de ago. de 2012. 
Elster's ${ }^{57}$ considerations are that constituent assemblies are seldom selfcreated, since they generally have two external creators. On one hand there is an institution or individual that decides to convene the assembly and on another hand there is the institutional mechanism that selects the representatives. In this context, the author argues that there are upstream and downstream constraints. The upstream constraints are imposed before it begins to deliberate, that is, they determine or condition the participation in constituent assemblies. The downstream constraints must be accepted by means of a process, by the necessity of ratification of the produced document, which ends up conferring more legitimacy to its proposition.

In Germany, after World War II, the ally powers also reserved to themselves the right to approve the constitution before it was passed for approval by public referendum. Given this perception Elster ${ }^{58}$ reports that the division between upper or lower self-imposed control is somewhat arbitrary. Typically, lower controls are actually imposed by the higher authority.

The relation between the assembly and its creators can be summarized in two opposite statements: "let the one who establishes the king serve the king" versus "let the king serve who establishes him".

And experimentally Elster ${ }^{59}$ suggests the following recommendations: elections for constituent assemblies must follow the proportional system to the detriment of the majority; they must be unicameral and not bicameral; the role of experts should be kept to a minimum because solutions tend to be more stable if dictated by policy to the detriment of technical considerations; one should work with a time limit, so that no group can use postponement tactics to achieve its goals; they should not be effective immediately after its adoption to reduce the impact of short-term and party motives.

Of the countries in which the UN intervention was considered strong, the average construction of the charter was relatively short ${ }^{60}$, such as in Afghanistan, in two years and one month; Bosnia, in six months; Iraq, in one year and seven months; Kenya, in one year and eight months. The constitutional drafting

57 ELSTER, Jon. Forças e mecanismos no processo de elaboração da constituição. Trad. Eliana Valadares Santos. In: BIGONHA, Antônio Carlos Alpino; MOREIRA, Luiz (Org.). Limites do controle de constitucionalidade. Rio de Janeiro: Lúmen Juris, 2009, p. 18-21.

58 ELSTER, Forças e mecanismos no processo de elaboração da constituição. Trad. Eliana Valadares Santos. In: BIGONHA, Antônio Carlos Alpino; MOREIRA, Luiz (Org.). Limites do controle de constitucionalidade. Rio de Janeiro: Lumen Juris, 2009, p. 18-21.

59 ELSTER, Jon. Forças e mecanismos no processo de elaboração da constituição. Trad. Eliana Valadares Santos. In: BIGONHA, Antônio Carlos Alpino; MOREIRA, Luiz (Org.). Limites do controle de constitucionalidade. Rio de Janeiro: Lumen Juris, 2009, p. 39-40.

60 INSTITUTO INTERNACIONAL PARA LA DEMOCRACIA Y LA ASISTENCIA ELECTORAL. Reconciliacion luego de conflictos violentos: resumen de políticas. Stockholm, 2003. Disponível em: <http://www.idea.int/publications/reconciliation/upload/policy_summary_esp. pdf $>$. Acesso em: 05 de nov. de 2015. 
committee in Afghanistan was composed of nine members selected by the UN and later the commission was enlarged to thirty-five members, mainly politicians and relevant experts.

The Bosnian charter was drafted by delegates in the peace agreements and the members of the "contact group" were represented by the Assistant Secretary of the United States, Richard Holbrooke, and by American mediators and experts.

There is a broad consensus that the participation of external actors in the constituent process should be reduced. In this sense, there is no concern with form, that is, the formalistic facade of the construction method of the constitution, but there is a concern with who is part of the process.

Being part of the constituent process with legal and technical knowledge expertise - which includes the structure and fundamental principles - does not necessarily mean being part of the process as a political actor. An external force, with a political capacity for interference, can contaminate the choices and empty the action of the local community and social forces. Even because a constitutional text only makes sense if one knows the plurality of its sources.

\subsection{PROPOSED SUBSTANTIVE DEMOCRACY}

Feldman ${ }^{61}$ argues that "imposed constitutionalism", understood here in its material and substantial form, ultimately shapes the conflict between the principles of equality and autonomy. Advocates of equality, often international actors, are pushing for a constitutional guarantee that expressly triumphs over any other device. For democratic theory, the conflict between autonomy and equality cannot be easily solved or explained.

Souza Santos ${ }^{62}$ alerts us to the tension between the universal and the foundational. It is said that what is valid independent of context at any time and place is universal and is representative because of its breadth. The foundational is something that has transcendental importance because it is unique. It represents a specific identity that has memory, history, and roots, and its unique and specific character can be as powerful a force as the universality and generality of the universal. Any of these values, universal or fundamental, is nowadays one that has ultimate legitimacy, even though both end up producing exclusions. It is these values that now constitute the source of tension between the principle of equality and the principle of recognition of difference.

What we consider universal today is the foundational of the West transformed into global. For Souza Santos ${ }^{63}$ it is a "globalized localism". Over

61 FELDMAN, Noah. Imposed constitutionalism. Connecticut Law Review, Vol. 37, 2004/2005, p. 857.

62 SOUZA SANTOS, Boaventura. Derechos humanos, democracia y desarrollo. Bogotá: Centro de Estudios de Derecho, Justicia y Sociedad, Dejusticia, 2014, p. 37.

63 SOUZA SANTOS, Boaventura. Derechos humanos, democracia y desarrollo. Bogotá: Centro 
the past five centuries, the West's economic, political, military, and cultural hegemony has been able to convert what was, or what was supposed to be unique and specific to this region of the world into something general. It is the product of the historical transformation of the Western Eurocentric foundation through the process of globalization of colonialism and capitalism.

The universal conception of what equality requires takes different forms in different societies, because its evolution, culture and history is what ultimately determines the meaning of its laws and policies $^{64}$. It is this command that allows, for example, the construction of policies such as compulsory maternity leave in the United States and not compulsory in France and Sweden. A universal right has different signs in the particular universe here because it is influenced by its own constitutional identity and constitutional vision.

The role of transporting values and rules and this is the vector defined by its members, meaning, the reception of these principals in the terrain, according to Rich and Newman ${ }^{65}$, "tends to be more successful if the agents are uninterested in the results". Whoever wishes to adopt it, must automatically incorporate such principal and that will be considered democracy ${ }^{66}$.

The United Nations has played a role in the coercive promotion of human rights, as well as more functional technical assistance, such as in Somalia, Haiti and East Timor ${ }^{67}$. According to Rich and Newman ${ }^{68}$, one of the main reasons for adherence to human rights is to ensure that minimum substantive rights are respected in newly democratized nations. The unrestrained imposition of these rights may directly conflict with the principles of self-determination or national autonomy.

The culture and ideology of these organizations are committed to universal vision and the highly symbolic nature of membership reflects a trend of global models ${ }^{69}$. Three historical perspectives can confirm this trend, according to

de Estudios de Derecho, Justicia y Sociedad, Dejusticia, 2014, p. 38-39.

64 HELLMAN, Deborah. Comments on Michel Rosenfeld's the identity of the constitutional subject: selfhood, citizenship, culture, and community. Cardozo Law School Legal Studies Research Paper, Vol. 348, 2012, p.1844. Disponível em: <http://cardozolawreview.com/content/33-5/Hellman.33-5.pdf>. Acesso em: 24 de out. de 2014.

65 RICH, Roland; NEWMAN, Edward. Approaching democratization policy. In: NEWMAN, Edward; RICH Roland. (Ed.). The UN role in promoting democracy: between ideals and reality. Tokyo, New York, Paris: United Nations University Press, 2004, p.29.

66 FELDMAN, Noah. Imposed constitutionalism. Connecticut Law Review, Vol. 37, 2004/2005, p. 865.

67 RICH, Roland; NEWMAN, Edward. Approaching democratization policy. In: NEWMAN, Edward; RICH Roland. (Ed.). The UN role in promoting democracy: between ideals and reality. Tokyo, New York, Paris: United Nations University Press, 2004, p.11.

68 RICH, Roland; NEWMAN, Edward. Approaching democratization policy. In: NEWMAN, Edward; RICH Roland. (Ed.). The UN role in promoting democracy: between ideals and reality. Tokyo, New York, Paris: United Nations University Press, 2004, p.11-13.

69 BECK, Colin J; DRORI, Gili S; MEYER, John W. World influences on human rights language 
Beck, Drori and Meyer ${ }^{70}$ : the language of human rights can be a product of characteristics of the regime and history more common among democracies, states and modernization and those countries that seek to reconciliation after authoritarian and oppressive episodes; the adoption of international norms may reflect formal or informal links of rights between the nation-state and the international system; and the national framework reflects the global environment of human rights at the time of adoption of the charter particularly for the emerging and peripheral states, most exposed to the world order.

Many treaties and other global instruments establish a matrix that has the primary purpose of dissemination. Most constitutions, especially in conflict countries, present a universalist understanding of human rights. Many principles end up not being consistent with national culture, although this language is the product of democracy and a modern liberal view of citizenship embodied in "democratic" regimes. This status may be more pronounced in post-conflict nations, since institutionalization of provisions also serves as a blocking clause against authoritarian opponents.

In addition, the language reflects the connection with the world community. The multilateral character of international organizations, such as the UN and the World Bank, operates in line with international human rights standards ${ }^{71}$.

This statement is the result of a research developed by Beck, Drori and Meyer ${ }^{72}$, which analyzed 189 letters, tracing the references referring to human rights and reaching the conclusion that about $60 \%$ of them make at least one mention. Countries with stories of torment and influenced by UN intervention such as Bosnia, East Timor, Haiti, El Salvador, Uganda, and Guatemala, tend to classify more broadly and abstractly the terms of this language in their constitutions.

It is Feldman's ${ }^{73}$ claim that this adherence to human rights defenders is a real victory, but it can also represent an internationalization or unbridled domestication of international law regimes in nations without a democratic tradition.

in constitutions: a cross-national study (2012). International Sociology, 2012, Vol. 27, p. 2.

70 BECK, Colin J; DRORI, Gili S; MEYER, John W. World influences on human rights language in constitutions: a cross-national study (2012). International Sociology, 2012, Vol. 27, p. 2.

71 BECK, Colin J; DRORI, Gili S; MEYER, John W. World influences on human rights language in constitutions: a cross-national study (2012). International Sociology, 2012, Vol. 27, p. 7.

72 For access to researcher BECK, Colin J; DRORI, Gili S; MEYER, John W. World influences on human rights language in constitutions: a cross-national study (2012). International Sociology, 2012, Vol. 27, p.1-30.

73 FELDMAN, Noah. Imposed constitutionalism. Connecticut Law Review, Vol. 37, 2004/2005, p. 867. 
Gargarella ${ }^{74}$ announces that the growing weight of international norms in charters ends up adding a complexity of meanings to the local community. Norms often refer to inaccurate content, and there is no clear way to interpret it, especially in newly democratized countries.

The authority of international bodies with some degree of legitimacy is not denied at all, especially when the intention is to reverse the framework of instability experienced by non-democratic regimes. But if there is no clear way of interpreting it, most laws and international rules are rarely enforced but generally obeyed $^{75}$.

For $\mathrm{Koh}^{76}$, if the goal is a better application of the general, global rules, obedience must be voluntary and its fulfillment cannot be coerced - nations, perceiving that a rule is "fair," are more inclined to respect it.

This can occur with the interference of the international actors in the process of construction of the new order. In these interactions, it is possible to discuss with local elite's interpretative statements of the world norm that would be appropriate to the concrete situation. In doing so, the actors do not simply seek to coerce the other party, but rather to integrate it into the normative system, with the aim of making the community identify this interpretation as part of its set of values. There would be a perfect alignment between the moral, political and legal dimension of human rights, for example a global consensus on the import of these rights.

According to Rosenfeld ${ }^{77}$, in such a scenario, the transition to political and legal domains would be easy and seamless, and democratic integration by a globally unified and politically indivisible subject would be purely formal and apparently superficial.

Ensuring respect for human rights in nations is a fundamental worldwide trend, whether for the maintenance of the nation - survival - or to ensure the least protection for the human being.

Its incorporation into constitutional charters is a necessity, since it is not possible to agree with its systemic violation if it will effectively contribute to human, social and political development. But this process must be normative,

74 GARGARELLA, Roberto. La sala de máquinas de la Constitución: dos siglos de constitucionalismo en América Latina (1810-2010). Buenos Aires: Katz Editores, 2015, p. 306.

$75 \mathrm{KOH}$, Harold Hongju. Why do nations obey international law? The Yale Law Journal, Vol. 106, 1997, p. 2604. Disponível em: <http://digitalcommons.law.yale.edu/cgi/viewcontent. cgi? article=2897\&context=fss_papers $>$. Acesso em 13 de mai. de 2014.

$76 \mathrm{KOH}$, Harold Hongju. Why do nations obey international law? The Yale Law Journal, Vol. 106, 1997, p. 2645. Disponível em: <http://digitalcommons.law.yale.edu/cgi/viewcontent. cgi? article=2897\&context=fss_papers $>$. Acesso em: 13 de mai. de 2014 .

77 ROSENFELD, Michel. The Constitutional subject, its other, and the perplexing quest for an identity of its own: a replay to my critics. Cardozo Law Review, Vol. 358, 2012, p. 1950. Disponível em: <http://papers.ssrn.com/sol3/papers.cfm?abstract_id=2021356>. Acesso em: 23 de jun. de 2014. 
dynamic and constitutive. Benhabib ${ }^{78}$ associates these rights with that of "selfgovernment", which is exercised through appropriate political channels, since their defense are limits of the exercise of public power and therefore requires the civic-republican vision that is formed by the exercise that comes from the public autonomy of citizens.

\section{CONCLUSION}

Whether in the pre-constituent phase, or in the constituent phase, we are addressing political-legal processes in which a global international organization interferes with the adoption or reform of a constitution by a national state. The fact is revealing, first of all, of the political, economic and social fragility of certain parts of the world - subject to fratricidal disputes that include violence and the subjection of considerable portions of their populations. Secondly, the fact reveals the difficulty that the global international system finds to position itself adequately in the face of the problem without the marks of colonization.

Two attempts, one at the national level, the other at the international level, have been pressing forward, albeit showing their inadequacies. In nationalism, the attempt has been to let states (or quasi-states) solve their problems, including the constitutional definition, in the name of the principle of the free determination of peoples, and recalls situations in which internal violence is unleashed, due to the local political incapacity to solve the problems in an autonomous way. On the plane of internationalism, the attempt presented is hard intervention, so that a higher moral and political entity determines the initial rules of coexistence of a people, which is done with the principle of internationalization of social relations and defense of universal human rights. Both alternatives are insufficient to adopt maximalist perspectives, which demonstrate inability to construct appeasement. If we are talking about appeasement, it seems appropriate for international intervention to take place in a concerted manner with the national community to which it refers.

\section{REFERENCES}

ARATO, Andrew. Construção constitucional e teorias da democracia. Lua Nova: Revista de Cultura e Política [on line]. 1997, n 42, p. 5-51. Disponível em: $<$ http://www.scielo.br/pdf/ln/n42/a02n42.pdf>. Acesso em: 24 de ago. de 2012.

BECK, Colin J; DRORI, Gili S; MEYER, John W. World influences on human rights language in constitutions: a cross-national study (2012). International Sociology, 2012, Vol. 27, p1-30.

78 BENHABIB, Seyla. On Michel Rosenfeld's the identity of the constitutional subject. Cardozo Law Review, Vol. 33, 2011, p.1905. Disponível em: <http://cardozolawreview.com/content/33-5/Benhabib.33-5.pdf>. Acesso em: 23 de jun. de 2014. 
BONEO Horacio; CARRILLO, Manuel; VALVERDE, Ricardo. La observación internacional y nacional de las elecciones. In: NOHLEN Dieter, ZOVATTO Daniel, OROZCO Jesús, THOMPSON José (Org.). Tratado de Derecho Electoral comparado de América Latina. 2. ed. México: Fondo de Cultura Económica, Instituto Interamericano de Derechos Humanos, Universidad de Heidelberg, International IDEA, Tribunal Electoral del Poder Judicial de la Federación, Instituto Federal Electoral, 2007, p.1072-1107.

BENHABIB, Seyla. On Michel Rosenfeld's the identity of the constitutional subject. Cardozo Law Review, Vol. 33, 2011, p.1889-1906. Disponível em: <http://cardozolawreview.com/content/33-5/Benhabib.33-5.pdf>. Acesso em: 23 de jun. de 2014.

CATÓN, Matthias. Effective party assistance: stronger parties for better democracy. Stockholm: International IDEA, 2007.

COLLIER, Paul; HOEFFLER, Anke. The challenge of reducing the global incidence of civil war. Copenhagen Consensus Challenger Paper. Centre for the Study of African Economies, Department of Economics, Oxford University, Março 2004. Disponível em: <http://www.copenhagenconsensus.com/sites/default/files/ CP\%2B\%2BConflicts\%2BFINISHED.pdf>. Acesso em: 25 de nov. de 2014.

CÓlON-RIOS, Joel. Apuntes sobre legitimidad democrática y asambleas constituyentes. Revista Argentina de Teoría Jurídica, Vol. 16, Dezembro de 2015, p.1-11. Disponível em: <http://www.utdt.edu/ver_contenido.php?id_ contenido=111698id_item_menu=5858>. Acesso em: 8 de jan. de 2016 .

ELSTER, Jon. Forças e mecanismos no processo de elaboração da constituição. Trad. Eliana Valadares Santos. In: BIGONHA, Antônio Carlos Alpino; MOREIRA, Luiz (Org.). Limites do controle de constitucionalidade. Rio de Janeiro: Lúmen Juris, 2009, p. 9-40.

FELDMAN, Noah. Imposed constitutionalism. Connecticut Law Review, Vol. 37, 2004/2005, p. 857-889.

GARGARELLA, Roberto. La sala de máquinas de la Constitución: dos siglos de constitucionalismo en América Latina (1810-2010). Buenos Aires: Katz Editores, 2015 .

GOUVÊA, Carina Barbosa. O direito fundamental à saúde, um olhar para além do reconhecimento: construindo a efetivação que opera em favor da democracia e do desenho institucional. Brasília/DF: Gomes \& Oliveira Editora, 2015, p. 204.

. GOUVÊA, Carina B. As Intervenções da ONU no Processo de ConstitutionMaking nos Estados em Transição Política: O Papel das Nações Unidas no Resgate da Ordem Democrática. 1. ed. Curitiba/PR: Juruá Editora, 2016.

HAMPSON, Fen Osler. Can peacebuilding work. Cornell International Journal, 
Volume 30, no 3, Artigo 5, 1997, p. 701-716. Disponível em: <http://scholarship. law.cornell.edu/cilj/vol30/iss3/5>. Acesso em: 30 de abr. de 2015.

HELLMAN, Deborah. Comments on Michel Rosenfeld's the identity of the constitutional subject: selfhood, citizenship, culture, and community. Cardozo Law School Legal Studies Research Paper, Vol. 348, 2012, p.1839-1846. Disponível em: <http://cardozolawreview.com/content/33-5/Hellman.33-5.pdf>. Acesso em: 24 de out. de 2014.

HESSE, Konrad. A força normativa da constituição. Trad. Gilmar Ferreira Gomes. Porto Alegre: Sérgio Antônio Fabris, 1991.

HIPPEL, Karin von. Democracia pela força. Trad. Joubert de Oliveira Brízida. Rio de Janeiro: Biblioteca do Exército Brasileiro (Editora), 2003.

HIRSCHL, Ran. From comparative constitutional law to comparative constitutional studies. International Journal Constitutional Law, 2013, v. $11 \mathrm{n}^{\circ}$ 1, p. 1-12.

HUNTINGTON, Samuel P. The third wave: democratization in the late twentieth century. University of Oklahoma Press: Norman and London, 1991.

INSTITUTO INTERNACIONAL PARA LA DEMOCRACIA Y LA ASISTENCIA ELECTORAL. Reconciliacíon luego de conflictos violentos: resumen de políticas. Stockholm, 2003. Disponível em: <http://www.idea.int/publications/ reconciliation/upload/policy_summary_esp.pdf>. Acesso em: 05 de nov. de 2015.

$\mathrm{KOH}$, Harold Hongju. Why do nations obey international law? The Yale Law Journal, Vol. 106, 1997, p.2599-2659. Disponível em: <http://digitalcommons. law.yale.edu/cgi/viewcontent.cgi? article=2897\&context=fss_papers $>$. Acesso em: 13 de mai. de 2014.

LAPPIN, Richard. What democracy? Exploring the absent center of post-conflict democracy. Assistance Journal of Peace Conflict and Development, $\mathrm{N}^{\circ} 14$, Jul 2009, p.1-32. Disponível em: <www.peacestudiesjournal.org.uk>. Acesso em: 05 de ago. de 2015.

MCCOOL Carolyn. The Role of Constitution-Building Processes in Democratization: Afghanistan Case Study (Intl IDEA,2004.

MICHAEL, Stephan; COFONE, Ignacio N. Fixing popular participation in constitution-making. Rotterdam Institute of Law and Economics, Erasmus University Rotterdam, No 2015/02, p.1-23. Disponível em: <http://ssrn.com/ abstract $=2580849>$. Acesso em: 15 mai. de 2015.

REILLY, Benjamin. Electoral assistance and post-conflict peacebuilding: what lessons have been learned? Asia Pacific School of Economics and Government Australian National University, Vol. 200, 2004, p. 1-26. Disponível em: <http:// 
aceproject.org/ero-en/topics/elections-security/Reilly-2505.pdf>. Acesso em: mar. de 2014.

REYNOLDS, Andrew; REILLY, Ben; ELLIS, Andrew. Diseño de sistemas electorales: el nuevo manual de IDEA Internacional. Trad. Carlos Navarro Fierro. IDEA Internacional, 2006.

RICH, Roland; NEWMAN, Edward. Approaching democratization policy. In: NEWMAN, Edward; RICH, Roland. (Ed.). The UN role in promoting democracy: between ideals and reality. Tokyo, New York, Paris: United Nations University Press, 2004, p.3-31.

RICHIE, David. Pertencimento constitucional. Trad. Izabel Nuñez. In: ASENSI, Felipe Dutra; DE PAULA, Daniel Giotti (Coord.). Tratado de direito constitucional: constituição, política e sociedade. Vol I. Rio de Janeiro: Elsevier, 2014.

ROSENFELD, Michel. The constitutional subject, its other, and the perplexing quest for an identity of its own: a replay to my critics. Cardozo Law Review, Vol. 358, 2012, p. 1937-1970. Disponível em: <http://papers.ssrn.com/sol3/papers. cfm?abstract_id=2021356>. Acesso em: 23 de jun. de 2014.

SAMUELS, Kirsti. Post-Conflict peace-building and constitution-making. Chicago Journal of International Law, V. 6, N² 2, 2006, p. 663-682. Disponível em: <http:// chicagounbound.uchicago.edu/cgi/viewcontent.cgi? article=1476\&context=cjil $>$. Acesso em: 17 de jan. de 2014.

SOUZA SANTOS, Boaventura. Derechos humanos, democracia y desarrollo. Bogotá: Centro de Estudios de Derecho, Justicia y Sociedad, Dejusticia, 2014.

TEITEL, Ruti G. Transitional justice genealogy. Harvard Human Rights Journal,Vol. 16, 2003, p. 69-94. Disponível em: <http://www.law.harvard.edu/ students/orgs/hrj/iss16/teitel.pdf>. Acesso em: 11 dez. de 2012.

TEN HOOVE, Lotte; SCHOLTBACH, Alvaro Pinto; MAUL-PHILLIPS, Joy. Democracy and political party assistance in post-conflict societies. Netherlands Institute for Multiparty Democracy, NIMD Knowledge Centre, 2008.

TOLER, Lorianne Updike. Mapping the constitutional process. Cambridge Journal of International and Comparative Law, Vol.3 nº 4, 2014, p. 1260-1286. Disponível em: <http://cjicl.org.uk/archive/>. Acesso em: 18 de ago. de 2015.

TUSHNET, Mark.Novos mecanismos institucionais para a criação do direito constitucional. Trad. Thiago Filippo Silva Jorge. Quaestio Iuris, Vol. 08, nº 02 , Rio de Janeiro, 2015.

WIDNER, Jennifer. Constitution writing in post-conflict settings: an overview. William \& Mary Law Review, Vol. 49, Issue 4, 2008, p. 1513-1541. 
UNITED NATIONS ASSISTANCE TO CONSTITUTION-MAKING PROCESSES

WORKSHOP ON CONSTITUTION BUILDING PROCESSES, 2007. Nova Jersey. Workshop Report. Nova Jersey: Bobst Center for Peace \& Justice; Princeton University; International IDEA, 2007.

Recebido em: 13/03/2019.

Aprovado em: 20/08/2019. 